\title{
PENGEMBANGAN ALAT PERMAINAN KERANJANG PINTAR DALAM PEMBELAJARAN BERBICARA ANAK KELOMPOK B DI TAMAN KANAK-KANAK
}

\author{
Mega Fitria Herdiati, Usep Kustiawan, Suryadi \\ Universitas Negeri Malang, Jalan Semarang 5 Malang 65145 \\ Email: fidtafitria@yahoo.com
}

\begin{abstract}
The Development of Educational Smart Basket in Learning Speaking Child Group $\mathrm{B}$ in Kindergarten. This research is aimed to produce a good educational Smart basket for the children of group B of Sejahtera Malang Kindergarten. This research is a Research and Development which used Dick and Carey model. The subject of this research is 25 children of group B of Sejahtera Malang Kindergarten. The methods applied in the data collection are questionnaire, interview, and live observation. The data analysis of this research employed technique qualitative and quantitative descriptive analysis in the form of percentages. The result of the research shows that the smart game tool is categorized as very valid, very effective, very complete, and educational game tool is declared worthy to be used as a learning media for children of group B of Sejahtera Malang Kindergarten.
\end{abstract}

Keywords: gaming equipment development, smart basket, speaking

\begin{abstract}
Abstrak: Pengembangan Alat Permainan Keranjang Pintar dalam Pembelajaran Berbicara Anak Kelompok B di Taman Kanak-kanak Tujuan penelitian ini adalah untuk menghasilkan alat permainan keranjang pintar yang layak untuk anak kelompok B. Jenis penelitian ini adalah penelitian Research and Development dengan model Dick and Carey. Subjek dalam penelitian ini adalah 25 anak kelompok B di TK Sejahtera Malang. Metode yang digunakan dalam pengumpulan data adalah angket, lembar wawancara, dan lembar observasi. Analisis data penelitian menggunakan teknik analisis kualitatif dan kuantitatif berupa persentase. Hasil penelitian menunjukkan bahwa alat permainan keranjang pintar dikategori sangat valid, sangat efektif, sangat tuntas, dan alat permainan edukatif ini dinyatakan layak digunakan sebagai media pembelajaran untuk anak kelompok B di TK Sejahtera Malang.
\end{abstract}

Kata kunci: alat permainan, keranjang pintar, berbicara

Pada zaman sekarang ini, orang dituntut untuk mengembangkan kemampuan fisik, kognitif, bahasa, sosial emosional, seni, moral, dan nilainilai agama anak. Aisyah, dkk., (2014) menyatakan anak usia dini sering disebut dengan istilah golden age atau usia emas karena pada rentang usia ini anak mengalami pertumbuhan dan perkembangan yang sangat pesat pada berbagai aspek. Anak memiliki karakteristik tertentu yang khas dan tidak sama dengan orang dewasa serta akan berkembang menjadi manusia seutuhnya. Menurut Sujiono (2012) anak usia dini adalah sosok individu yang sedang menjalani suatu proses perkembangan dengan pesat dan fundamental bagi kehidupan selanjutnya. Anak memiliki berbagai macam potensi yang harus dikembangkan, meskipun pada umumnya anak memiliki pola perkembangan yang sama tetapi ritme perkembangan akan berbeda satu sama lainnya karena pada dasarnya anak bersifat individual. Salah satu aspek yang perlu dikembangkan anak usia dini adalah aspek bahasa. Melalui bahasa, anak dapat mengekspresikan pikiran sehingga orang lain memahaminya dan menciptakan suatu hubungan sosial. Anak perlu menggunakan bahasa agar dapat mengetahui dan memahami dengan baik. Menurut Frasiska (2014) perkembangan bahasa dan berbicara merupakan proses yang berjalan beriringan.

Berbicara merupakan bentuk komunikasi umum yang digunakan semua orang tak terkecuali 
anak-anak. Hurlock (1995) mengatakan bahwa kemampuan berbicara memenuhi kebutuhan penting lainnya dalam kehidupan anak, yakni kebutuhan untuk menjadi bagian dari kelompok sosial. Terdapat banyak cara untuk mengembangkan bahasa anak, salah satunya adalah melalui permainan. Montolalu, dkk., (2005) mengemukakan salah satu pendekatan pembelajaran di Taman Kanak-kanak adalah belajar sambil bermain dan bermain sambil belajar. Berdasarkan pengamatan di TK Sejahtera Malang anak kelompok B memiliki permasalahan yang bervariasi, misalnya dalam kegiatan pembelajaran jarang sekali guru menyiapkan alat permainan yang menarik bagi anak dan juga alat permainan yang digunakan kurang bervariasi. Selama ini dalam pembelajaran untuk mengembangkan kemampuan bahasa anak terutama dalam hal berbicara, guru hanya menerapkan kegiatan bercerita dan berbagi tentang pengalaman anak selama diluar sekolah. Berdasarkan uraian di atas, sehingga peneliti ingin mengembangkan suatu alat permainan keranjang pintar yang mudah, menyenangkan, aman, dan sesuai dalam pembelajaran berbicara anak.

Peneliti memilih alat permainan keranjang pintar karena anak usia dini menyukai permainan, begitu juga anak-anak di TK Sejahtera Malang. Melalui permainan akan membuat anak merasa senang, lebih bersemangat, dan dapat menjadi variasi permainan untuk menunjang pembelajaran di TK. Alat permainan keranjang pintar merupakan salah satu alat permainan yang digunakan dalam mengembangkan kemampuan berbicra anak. Permainan ini menggunakan keranjang dalam permainannya. Komponen dalam permainan keranjang pintar ini dapat menggunakan beraneka benda. Alat permainan ini diharapkan mudah, menyenangkan, aman, dan sesuai dalam pembelajaran berbicara anak. Selain mengembangkan kemampuan berbicara, permainan keranjang pintar juga mengembangkan kemampuan fisik motorik, kognitif, dan sosial emosional anak.

Alat permainan keranjang pintar ini dikembangkan dengan menggunakan kartu gambar dan kartu huruf, dengan menggunakan kartu gambar dan kartu huruf ini anak dapat mengembangkan kemampuan berbicara. Berbicara menggunakan kartu gambar dan kartu huruf ini dapat menambah kosa kata anak, selain dengan kartu gambar anak juga dapat mengenal benda asli dari kartu bergambar tersebut. Bahasa sebagai fungsi dari komunikasi yang memungkinkan dua individu atau lebih mengekspresikan ide, arti, perasaan, dan pengalaman. Hurlock (1995) mengemukakan bahwa "bahasa mencakup setiap sarana komunikasi dengan menyimbolkan pikiran dan perasaan untuk menyampaikan makna kepada orang lain.

Termasuk di dalamnya perbedaan bentuk komunikasi yang luas seperti: tulisan, bicara, bahasa symbol, ekspresi muka, isyarat, pantomime, dan seni. Dalam proses belajar dan pembelajaran guru sangat berperan penting dalam mengembangkan semua aspek perkembangan anak. Guru dalam proses pembelajaran yang utama adalah menyampaikan informasi. Menurut Yasin (2012) pembelajaran adalah suatu situasi yang tercipta dari interaksi yang berlangsung antara berbagai faktor (multiple factor) ataupun komponen; guru, anak (peserta didik), kurikulum, metode, sarana, dan media serta komponen lain yang diperlukan. Bicara menjadi alat yang membantu dalam perkembangan suatu bahasa yang formal. Bicara anak adalah suatu penyampaian maksud tertentu dengan mengucapkan bunyi-bunyi bahasa supaya bunyi tersebut dapat dipahami oleh orang yang ada dan mendengarkan di sekitarnya (Suhartono, 2005).

Alat permainan adalah alat yang sengaja dirancang untuk mengembangkan aspek-aspek perkembangan. Menurut Kustiawan (2013) alat permainan adalah semua alat bermain yang digunakan oleh anak untuk memenuhi naluri bermainnya, sehingga menghasilkan pengertian, memberikan informasi, memberikan kesenangan, dan mengembangkan seluruh aspek pengembangannya. Alat permainan ini juga dapat disebut dengan alat permainan edukatif. Aat permaianan edukatif untuk anak usia dini adalah alat permainan yang dirancang untuk tujuan meningkatkan aspek-aspek perkembangan anak usia dini (Eliyawati, 2005). Dalam memilih alat permainan, guru sebaiknya memperhatikan manfaat alat permainan yang digunakan. Menurut Eliyawati (2005) alat permainan edukatif berfungsi mendorong anak untuk beraktifitas dan bersifat konstruktif atau menghasilkan sesuatu.

Keranjang pintar merupakan salah satu alat permainan yang terbuat dari bahan plastik dan karton yang berbentuk keranjang dan telah dihias. 
Alat permainan ini diciptakan untuk di mainkan oleh anak usia 5-6 tahun dalam pembelajaran berbicara. Alat permainan keranjang pintar ini berbentuk kotak yang berukuran $11 \mathrm{~cm}$ x $11 \mathrm{~cm}$ dengan tinggi $6 \mathrm{~cm}$ yang diberi kertas warna-warni agar menarik bagi anak. Pada saat memainkan alat permainan keranjang pintar ini, anak dapat mengembangkan kemampuan membaca dan menghitung benda yang ada di dalam keranjang yang dibawa oleh anak.

\section{METODE}

Metode yang digunakan dalam penelitian ini adalah model penelitian dan pengembangan (Research and Development). Dalam penelitian dan pengembangan pembelajaran anak usia dini yang berbentuk alat permainan keranjang pintar untuk kemampuan berbicara anak kelompok B, peneliti menggunakan model pengembangan (research and development) Dick dan Carey (2001) yang terdiri dari sepuluh langkah. Penelitian dan pengembangan ini hanya dilakukan dalam 1 sekolah yaitu TK Sejahtera Malang dengan subjek yang digunakan hanya 25 anak. Namun pada penelitian ini terbatas pada langkah ke sembilan karena hanya sebatas untuk mengembangkan permainan dan juga pada tahap ke sembilan sudah dapat mewakili bahwa alat permainan keranjang pintar dinyatakan valid atau tidak valid sehingga akan diketahui permainan ini layak digunakan atau tidak layak digunakan.

Tahap-tahap pelaksanaan uji coba produk, yaitu desain uji coba, subjek uji coba, jenis data, instrument pengumpulan data, dan teknik analisis data. Desain uji coba dilakukan untuk memperoleh data yang digunakan untuk menyempurnakan produk yang akan dibuat melalui tiga tahap, yaitu evaluasi dari para ahli (ahli bahasa, ahli pembelajaran anak usia dini, dan ahli permainan), uji coba perorangan (dengan menggunakan 2 anak sebagai subjek), uji coba kelompok kecil (dengan menggunakan 5 anak sebagai subjek), dan uji coba kelompok besar (dengan menggunakan 20 anak sebagai subjek).

Jenis data yang digunakan dalam penelitian ini merupakan data kualitatif dan data kuantitatif. Data kualitatif merupakan data dari berbagai tinjauan para ahli yang berupa saran, masukan, dan wawancara terhadap guru. Data kuantitatif diperoleh dari data uji coba kelompok kecil dan uji coba lapangan melalui observasi pada kegiatan yang menggunakan "Alat Permainan Keranjang Pintar". Data yang diperoleh yaitu bagaimana anak mudah melakukan, keamanan anak, anak senang, dan sesuai dalam pembelajaran berbicara.

Instrumen pengumpulan data yang digunakan dalam penelitian "Pengembangan Alat Permainan Keranjang Pintar Dalam Pembelajaran Berbicara Anak Kelompok B di Taman Kanak-Kanak" adalah dengan menggunakan pendekatan kualitatif dan kuantitatif yang berupa angket, lembar wawancara, dan lembar observasi. Angket digunakan untuk mengumpulkan data kuantitatif dari para ahli, lembar observasi digunakan untuk mengumpulkan data kuantitatif dari proses selama kegiatan berlangsung. Sedangkan data kualitatif diperoleh dari evaluasi para ahli berupa kritik, saran, dan masukan terhadap rancangan produk.

Teknik analisis data yang digunakan dalam penelitian dan pengembangan ini serta evaluasi para ahli untuk uji coba adalah teknik analisis kualitatif dan kuantitatif berupa persentase. Analisis kualitatif digunakan untuk menganalisis pengumpulan data dari para ahli dengan menggunakan data kualitatif. Data diperoleh dari ahli bahasa, ahli pembelajaran anak usia dini, dan ahli permainan berupa saran dan masukan yang digunakan untuk merevisi rancangan produk.

Analisis kuantitatif berupa persentase digunakan untuk mempersentase hasil pengumpulan data dari hasil validasi para ahli, hasil uji coba kelompok kecil dan hasil uji coba lapangan (kelompok besar). Rumus yang digunakan untuk menganalisis data kuantitatif menurut Akbar (2015) adalah:

$$
\begin{aligned}
& \qquad \mathrm{V}=\frac{\mathrm{TSe}}{\mathrm{TSh}} \times 100 \% \\
& \text { Keterangan: } \\
& \mathrm{V}=\text { Validitas } \\
& \mathrm{TSe}=\text { Total skor empirik (nilai hasil ujian } \\
& \text { kompetensi yang dicapai siswa) } \\
& \mathrm{TSh}=\text { Total skor maksimal (hasil uji } \\
& \text { kompetensi maksimal yang } \\
& \text { diharapkan dicapai siswa) }
\end{aligned}
$$

Berikut untuk mengetahui efektif-tidaknya implementasi model pembelajaran menurut Akbar (2015), dapat digunakan kriteria: 


\section{HASIL DAN PEMBAHASAN}

Peneliti mengembangkan Alat Permainan Keranjang Pintar dilakukan di TK Sejahtera Malang untuk mengatasi masalah yang ada, yaitu kurangnya variasi alat permainan dan media pembelajaran yang digunakan guru untuk anak. Berdasarkan pengumpulan data dari penyajian data uji coba akan disajikan hasil analisis data dari tinjauan para ahli, hasil uji coba perorangan, hasil uji coba kelompok kecil, dan hasil uji coba kelompok besar dalam pembelajaran berbicara anak kelompok B di TK Sejahtera Malang.

Hasil dari validasi ahli pembelajaran anak usia dini diperoleh hasil persentase $82,14 \%$, hasil dari validasi ahli permainan anak usia dini diperoleh persentase hasil $81,25 \%$, dan dari hasil validasi ahli bahasa anak usia dini diperoleh hasil persentase $96,42 \%$. Uji coba perorangan diperoleh hasil persentase aspek kemudahan 91,66\%, aspek keamanan $100 \%$, aspek kesenangan $100 \%$, keseuaian dalam pembelajaran berbicara $90 \%$. Uji coba kelompok kecil diperoleh hasil persentase aspek kemudahan 93,33\%, aspek keamanan $100 \%$, aspek kesenangan $100 \%$, kesesuaian dalam pembelajaran berbicara $88 \%$. Uji coba kelompok besar diperoleh hasil persentase aspek kemudahan $93,33 \%$, aspek keamanan $100 \%$, aspek kesenangan $100 \%$, kesesuaian dalam pembelajaran berbicara $96,08 \%$.

Berdasarkan dari keseluruhan data Tabel 2, diperoleh rata-rata hasil persentase sebesar 91,1\%. Berdasarkan kriteria tingkat kelayakan apabila permainan diuji cobakan tersebut, maka alat permainan Keranjang Pintar tergolong kategori sangat valid, sangat efektif, sangat tuntas, dapat digunakan tanpa perbaikan. Disimpulkan alat permainan Keranjang Pintar layak dan tepat sesuai digunakan sebagai salah satu alternatif dalam pembelajaran berbicara anak kelompok B yang mudah, aman, menyenangkan, dan sesuai dalam pembelajaran anak usia dini. Dengan demikian, hal tersebut sejalan dengan yang dikemukakan oleh Badru (2006) bahwa alat permainan edukatif dapat menumbuhkan motivasi, ketertarikan anak dan juga menciptakan suasana belajar yang menyenangkan sehingga proses pembelajaran memperoleh hasil yang optimal.

Berdasarkan unjuk kerja oleh anak terhadap alat permainan keranjang pintar, diperoleh temuan yaitu: (1) kemampuan fisik motorik anak yaitu kekuatan kaki dan tangan saat membawa keranjang dan melompat menginjak kartu gambar; (2) kemampuan sosial emosional anak yaitu mengendalikan emosi ketika menunggu giliran untuk maju kedepan; (3) kemampuan kognitif anak saat anak menghitung jumlah buah, dapat mengenal warna, dapat mengenal macam-macam buah; (4) kemampuan moral dan nilai agama yaitu mematuhi aturan permainan; (5) kemampuan bahasa anak saat anak menyusun huruf dan saat anak menyebutkan nama buah; dan (6) keampuan merasa dan membau saat anak merasakan dan mencium bau buah-buahan yang berbeda.

Produk pengembangan alat permainan keranjang pintar yang dilakukan di TK Sejahtera Malang, juga memiliki kelebihan-kelebihan yang bisa dimanfaatkan sebagai salah satu alternatif dalam pembelajaran berbicara di TK Sejahtera Malang dengan model permainan. Produk pengembangan alat permainan keranjang pintar yang dikemas dalam aktivitas pembelajaran berbicara melalui proses yang cukup panjang, mulai dari pembuatan rancangan produk hingga produk akhir terselesaikan dan juga beberapa tahapan yang telah dilalui, yaitu mulai dari tinjauan para ahli pembelajaran anak usia dini, ahli bahasa anak usia dini, dan ahli permainan anak usia dini, uji coba perorangan, uji coba kelompok kecil, dan uji coba kelompok besar.

Kelebihan dari penggunaan alat permainan ini selain dapat mengembangkan berbicara anak dalam pembelajaran berbicara terdapat banyak kelebihan, yaitu: (1) kemampuan fisik motorik anak yaitu kekuatan kaki dan tangan saat membawa keranjang dan melompat menginjak kartu gambar; (2) kemampuan sosial emosional anak yaitu mengendalikan emosi ketika menunggu giliran untuk maju kedepan; (3) kemampuan kognitif anak saat anak menghitung jumlah buah, dapat mengenal warna, dapat mengenal macam-macam buah; (4) kemampuan moral dan nilai agama yaitu mematuhi aturan permainan; (5) kemampuan bahasa anak saat anak menyusun huruf dan saat anak menyebutkan nama buah; dan (6) kemampuan merasa dan membau saat anak merasakan dan mencium bau buah yang berbeda. Berdasarkan data keseluruhan yang diperoleh dari uji coba kelompok besar, alat permainan keranjang pintar dalam pembelaja- 
Tabel 1 Kriteria Keefektifan Model Pembelajaran

\begin{tabular}{ccl}
\hline No & $\begin{array}{c}\text { Kriteria } \\
\text { Pencapaian Nilai } \\
\text { (Keefektifan) }\end{array}$ & \multicolumn{1}{c}{ Tingkat Efektifitas / Validitas } \\
\hline 1 & $81 \%-100 \%$ & Sangat valid, sangat efektif, sangat tuntas, dapat digunakan tanpa perbaikan \\
\hline 2 & $61 \%-80 \%$ & Cukup valid, cukup efektif, cukup tuntas, dapat digunakan namun perlu perbaikan kecil \\
\hline 3 & $41 \%-60 \%$ & $\begin{array}{l}\text { Kurang valid, kurang efektif, atau kurang tuntas, perlu perbaikan besar, disarankan tidak } \\
\text { dipergunakan }\end{array}$ \\
\hline 4 & $21 \%-40 \%$ & Tidak valid, tidak efektif, tidak tuntas, tidak bisa digunakan \\
\hline 5 & $0 \%-20 \%$ & Sangat tidak valid, sangat tidak efektif, sangat tidak tuntas, tidak bisa digunakan \\
\hline
\end{tabular}

Tabel 2 Hasil Uji Model

\begin{tabular}{clcc}
\hline No & \multicolumn{1}{c}{ Data yang diperoleh } & Persentase Validitas & $\begin{array}{c}\text { Total Skor Persentase } \\
\text { Maksimal }\end{array}$ \\
\hline A & Evaluasi Ahli & & \\
1 & Ahli Pembelajaran AUD & $82,14 \%$ & $100 \%$ \\
2 & Ahli Permainan AUD & $81,25 \%$ & $100 \%$ \\
3 & Ahli Bahasa AUD & $96,42 \%$ & $100 \%$ \\
B & Uji Coba Perorangan & $91,66 \%$ & $100 \%$ \\
1 & Kemudahan & $100 \%$ & $100 \%$ \\
2 & Keamanan & $100 \%$ & $100 \%$ \\
3 & Kesenangan & $90 \%$ & \\
4 & Kesesuaian & & $100 \%$ \\
C & Uji Coba Kelompok Kecil & $93,33 \%$ & $100 \%$ \\
1 & Kemudahan & $100 \%$ & $100 \%$ \\
2 & Keamanan & $100 \%$ & \\
3 & Kesenangan & $88 \%$ & $100 \%$ \\
4 & Kesesuaian & & $100 \%$ \\
D & Uji Coba Kelompok Besar & $93,33 \%$ & $100 \%$ \\
1 & Kemudahan & $100 \%$ & \\
2 & Keamanan & $100 \%$ & \\
3 & Kesenangan & $96,08 \%$ & \\
4 & Kesesuaian & & \\
\hline
\end{tabular}

ran berbicara anak usia 5 s.d. 6 tahun memiliki nilai kemudahan sebesar 93,33\%, kesenangan sebesar $100 \%$, keamanan sebesar $100 \%$, dan kesesuai dalam pembelajaran berbicara sebesar $91 \%$, semua dalam kategori sangat valid.

\section{SIMPULAN DAN SARAN}

Peneliti mengemukakan beberapa saran sehubungan dengan alat permainan yang dikembangkan. Saran-saran yang dikembangkan meliputi saran pemanfaatan, saran produksi masal, dan saran pengembangan lebih lanjut. Produk pengembangan ini adalah alat permainan keranjang pintar yang dapat digunakan oleh guru anak usia dini. Produk ini ditunjukkan untuk anak kelompok B dengan rentang usia 5 s.d. 6 tahun di TK Sejahtera Malang, namun produk ini juga dapat digunakan di sekolah lain. Begitu juga setting permainan tidak harus seperti buku panduan, setting permainan boleh dilakukan dimana saja didalam maupun diluar kelas dan membutuhkan ruang yang agak luas. Penyebaran produksi masal pada alat permainan keranjang pintar, peneliti memberikan saran sebaiknya disesuaikan dengan lingkup pengembangan yang akan dicapai dan terlebih dahulu buku panduan permainan disosialisasikan kepada sekolah-sekolah Taman Kanak-kanak, sehingga nantinya guru dapat mengetahui, memahami, dan melaksanakan sesuai dengan sasaran dan tujuan dari pengembangan alat permainan keranjang pintar. Produk dapat dibuat di pabrik atau di pengrajin dan dapat diberi hak cipta agar produk tidak ada yang meniru. Produk pengembangan dapat dipinjam tangankan jika telah memenuhi persyaratan, yaitu tidak disalah gunakan, tidak diduplikasikan, dan dapat menyesuaikan dengan tujuan penggunaan alat permainan. Sebelum menggunakan alat permainan ini sebaiknya disesuaikan denagn lingkup pengembangan yang akan dicapai. 


\section{DAFTAR RUJUKAN}

Aisyah, S. 2014. Perkembangan dan Konsep Dasar Pengembangan Anak Usia Dini. Tangerang Selatan: Universitas Terbuka.

Akbar, S.2015.Instrumen PerangkatPembelajaran. Bandung: PT Remaja Rosdakarya.

Badru, Z. 2006. Pengembangan Alat Permainan Edukatif untuk Anak Taman Kanak-kanak, (Online), (http://file.upi.edu/Direktori/FIP/ JUR._PGTK/197408062001121-BADRU ZAMĀN/pengembangan_APE_di_TK.pdf), diakses 2 Juli 2014.

Dhieni, N. 2009. Metode Pengembangan Bahasa. Jakarta: Universitas Terbuka.

Eliyawati, C. 2005. Pemilihan dan Pengembangan Sumber Belajar Untuk Anak Usia Dini. Jakarta: Departemen Pendidikan Nasional.

Frasiska, Y. M., dan Maryadi. 2014. Upaya Meningkatkan Keterampilan Berbicara Anak Kelompok A Melalui Metode Contektual Teaching and Learning (CTL) di Paud Daqu School Semarang Tahun Ajar 2013/2014. Jurnal Penelitian PAUDIA, 3(1), 175-185.
Hurlock, E. B. 1995. Perkembangan Anak. Jakarta: Erlangga.

Kustiawan, U. 2013. Sumber dan Media Pembelajaran Anak Usia Dini. Malang: Universitas Negeri Malang.

Montolalu, B. E. F. 2009. Bermain dan Permainan Anak. Jakarta: Universitas Terbuka.

Suhartono. 2005. Pengembangan Keterampilan Bicara Anak Usia Dini. Jakarta: Departemen Pendidikan Nasional.

Sujiono, Y. N. 2012. Konsep Dasar Pendidikan Anak Usia Dini. Jakarta: PT Indeks.

Yasin, S. 2012. Metode Belajar dan Pembelajaran yang Efektif. Jurnal Adabiyah, 12(1), 13-21. 